\title{
Dissolved arsenic in the shallow alluvial aquifers in North Brahmaputra Plain, India: a case study in and around lower Jia Bharali River basin
}

\author{
Nayan J. Khound ${ }^{1} \cdot$ Parag Phukon $^{2} \cdot$ Krishna G. Bhattacharyya ${ }^{3}$
}

Received: 18 September 2015/Accepted: 16 August 2017/Published online: 28 August 2017

(c) The Author(s) 2017. This article is an open access publication

\begin{abstract}
This study was carried out to investigate Arsenic (As) contamination in the alluvial aquifers of the lower Jia Bharali catchment and adjoining areas in Sonitpur district of Assam. Samples were collected twice a year (July and February) for three consecutive years from 50 monitoring wells spread into both older and younger alluvium between the Brahmaputra River towards south and Arunachal foothills towards north. The analytical results show that dissolved As content [both As(III) and As(V)] varies from below detection level (BDL) to $7.39 \mu \mathrm{g} / \mathrm{L}$ with a mean value of $1.92 \mu \mathrm{g} / \mathrm{L}$ and standard deviation of $1.37 \mu \mathrm{g} / \mathrm{L}$ during wet season (July). Thus, it remains within the WHO (2004) prescribed limit $(10 \mu \mathrm{g} / \mathrm{L})$ in the study area in the wet season. During the dry season, the range of variation is higher, from BDL to as much as $13.8 \mu \mathrm{g} / \mathrm{L}$ with a mean value of $2.57 \mu \mathrm{g} / \mathrm{Land}$ standard deviation of $2.23 \mu \mathrm{g} / \mathrm{L}$. About $78 \%$ of the wells show a concentration between 1 and $10 \mu \mathrm{g} / \mathrm{L}$ in both the seasons. However, only one of the wells present in foothills of Arunachal Himalaya was found to have As content higher than the WHO limit in the dry season. Along with total As, examination of concentration levels of other key parameters, viz., $\mathrm{Fe}, \mathrm{Mn}, \mathrm{Ca}, \mathrm{Na}, \mathrm{K}$, and $\mathrm{Mg}$ with $\mathrm{pH}$ and $\mathrm{SO}_{4}{ }^{2-}$ was also carried out. Most of the wells $(\sim 92 \%)$ showed Fe concentration much higher than the WHO (2004) permissible limit of $(0.3 \mathrm{mg} / \mathrm{L})$ particularly during the dry season and it is likely that high $\mathrm{Fe}$
\end{abstract}

Nayan J. Khound

njkhound@gmail.com

Department of Chemistry, Digboi College, Tinsukia, India

2 Department of Geological Sciences, Gauhati University, Guwahati, India

3 Department of Chemistry, Gauhati University, Guwahati, India concentration was responsible for keeping total As concentration at comparatively low levels. $34 \%$ of the samples in the wet seasons and $86 \%$ of the samples in the dry seasons have $\mathrm{Mn}$ above the permissible limit of $0.1 \mathrm{mg} / \mathrm{L}$.

Keywords Arsenic - Brahmaputra plain - Jia Bharali river basin · Iron · Alluvial aquifer

\section{Introduction}

The common forms of As (arsenite and arsenate oxyanions) in natural waters and their concentrations are usually determined by $\mathrm{pH}$, the redox potential, and such other factors that control the speciation and the mobility of As in the environment. Oxides and hydroxides of $\mathrm{Fe}(\mathrm{III}), \mathrm{Al}(\mathrm{III})$, or $\mathrm{Mn}(\mathrm{III} / \mathrm{IV})$, humic substances and clay minerals take up arsenic compounds and also influence the mobility of arsenic species within soils (Bissen and Frimmel 2003; Ali and Jain 2004; Ali et al. 2006, 2011, 2012).

Volcanic or geothermal eruptions, loellingite $\left(\mathrm{FeAs}_{2}\right)$, sulfide minerals as orpiment $\left(\mathrm{As}_{2} \mathrm{~S}_{3}\right)$, realgar (AsS), and mispickel (FeAsS) are the principal sources of environmental arsenic (Smedley and Kinniburgh 2002; Mandal and Suzuki 2002). The anthropogenic contributions of As results from industrial or agricultural activities: the smelting of arsenic bearing minerals, the burning of fossil fuels, the glass industry, arsenical pesticides, herbicides, and crop desiccants (Smedley and Kinniburgh 2002). The usual concentration of arsenic in groundwater varies between 1 and $10 \mu \mathrm{g} / \mathrm{L}$ (Bissen and Frimmel 2003; Sharma and Sohn 2009) and geochemical conditions of the aquifers that favor the mobilization and the accumulation of the anionic species of As are considered to be mainly responsible (Matin et al. 2004; Aloupi et al. 2009). Inorganic arsenic species 
are highly toxic, and various diseases, including lung cancer, liver cancer, renal cancer, and skin cancer or perturbations of the respiratory, gastrointestinal, cardiovascular, nervous, and hematopoietic systems, were associated with drinking water that is high in arsenic (Smith et al. 2002; Ali and Aboul-Enein 2002; Ali 2012).

The recognition of the scale of As enrichments in groundwater in West Bengal, India and Bangladesh and elsewhere has raised a serious concern in the scientific community. The Bengal delta plain, formed by the GangaPadma-Meghna-Brahmaputra river basin, covering several districts of West Bengal, India, and Bangladesh is considered as the high As-affected alluvial basin (Chetia et al. 2011). Arsenic contamination is identified as a major concern (Acharyya 2001) in the groundwater regime in the Gangetic delta covering southern part of West Bengal and Arsenic problem in Indian and NE Context. Recent studies have shown that in Assam, both in Brahmaputra valley and Barak valley many areas are arsenic prone, thus raising concern to human health in the region. However, although some assessments are being carried out recently which establish as many as eighteen districts of Assam as arsenic prone (Mahanta et al. 2015; Chetia et al. 2011) detail analysis and spatial variation of As contamination, taking into consideration the seasonal fluctuation of the aquifers are not yet available. There is also no definitive source linkages or mobilization mechanism established so far. In northeastern India, the presence of arsenic has been identified in 21 districts out of 24 districts of Assam and in three districts in Tripura, six in Arunachal Pradesh, one in Manipur, and two in Nagaland (Singh 2004; Mukherjee et al. 2006; Das et al. 2009). However, the problem of arsenic in groundwater and related health hazards in Assam is yet to get enough systematic attention due to its recent emergence having few review reports (Singh 2004; Mukherjee et al. 2006; Nickson et al. 2007; Chetia et al. 2008). Along with arsenic, the presence of high iron [both $\mathrm{Fe}(\mathrm{II})$ and $\mathrm{Fe}(\mathrm{III})]$ in water is another major issue in the region (Singh 2004; Ground Water Information Booklet 2008).Chronic and excess iron consumption is toxic for health, which might cause genetic disorders like hemochromatosis. This redox-flexible element produces oxygen-free radicals that are toxic to the cells. Moreover, iron hydroxides in water are supposed to help in the generation of arsenic species (Bhattacharjee et al. 2005). Recently, the problem of manganese has also come up in some parts of Assam (unpublished observation). Numerous pathologic conditions could occur as a consequence of excess persistent intake of manganese including behavioral changes and other nervous system disorders (Elster et al. 1988; ATSDR 2008). Again, the permissible limit for drinking water, according to the WHO, is $0.01 \mathrm{mg} / \mathrm{L}$
$(10 \mu \mathrm{g} / \mathrm{L})$, which is similar to the specification laid down by the Bureau of Indian Standards (BIS 1991; WHO 1993; Nickson et al. 2007); however, in India, according to the BIS (1991), the maximum permissible limit in the absence of an alternate source is $0.05 \mathrm{mg} / \mathrm{L}$.

This study presents the first set of detailed database showing spatiotemporal variation of arsenic in the alluvial unconfined shallow aquifers of north Brahmaputra plain south of the Arunachal Himalaya. The study area presents a pristine condition and as such the results presented here may be used as baseline data for further studies elsewhere in Assam and adjoining areas.

\section{Materials and methods}

\section{Site description}

The present study is focused on the Jia Bharali river catchment $\quad\left(92^{\circ} 00^{\prime}-93^{\circ} 25^{\prime} \mathrm{E}: 26^{\circ} 39^{\prime}-28^{\circ} 00^{\prime} \mathrm{N}\right) \quad$ localized within the Brahmaputra alluvium. The river flows orthogonal to the Himalayan thrust pattern through Arunachal Pradesh with the name Kameng, a state in the extreme northeast of India and deflecting along the Tipi Thrust in the north, enters the Brahmaputra plain just to the north of Bhalukpong $\left(92^{\circ} 65^{\prime} \mathrm{E}, 27^{\circ} 01^{\prime} \mathrm{N}\right)$ with its name the Jia Bharali. Extensive tea plantations and paddy fields occupy the higher and the lower topographic surfaces. The northern portion along the foothills of Arunachal Himalaya is made up of reserve forests and sparsely populated forestvillages. Older alluvium is found to be composed of partially indurated and oxidized sand, silt and clay which form higher topographic levels within an overall younger alluvial terrane of present day river deposits (Fig. 1). The study area falls in the subtropical climatic region and enjoys monsoon type of climate (Jain et al. 2007). The region abounds in bio-diversity with evergreen and deciduous trees of many types. The recorded maximum and minimum annual discharge of the Jia Bharali river at the gauging station N.T. Road Crossing (Jain et al. 2007) is 9,939 cusecs and 53 cusecs, respectively. The average annual suspended sediment load of the river recorded at this gauging site was 2143 ha-m (Jain et al. 2007). Moreover, high intensity rainfall erodes the top soil of the basin, landslides and slips also occur in many places which add high sediment load to the river. Two prominent soil types (light gray to dark gray and deep reddish) are seen in the studied area with low nitrogen, low phosphate, and medium to high potash contents. Acidic characters of the soil are representative of the soil cover found in the hills. In the plain areas, the other type of the soil covers is found to be feebly alkaline (Jain et al. 2007). 
Fig. 1 Alluvial pattern of Jia Bharali river basin showing younger and older alluviums

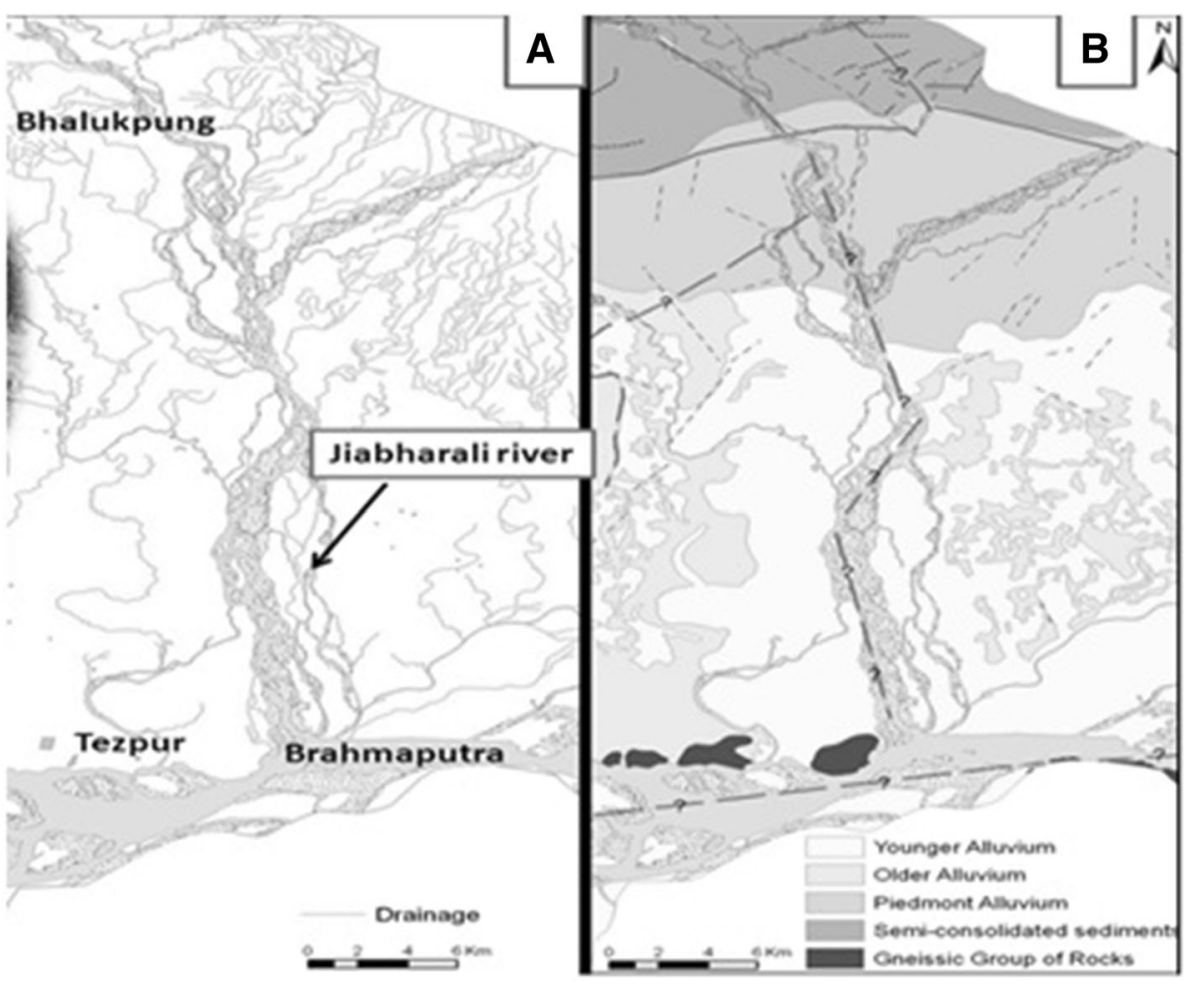

community use. Standard methods (APHA 1998) were followed in collection, storage and analysis of the 300 water samples (50 aquifers and six seasons). The shallow wells selected for this study have the variation of their depth as $2.53-15.10 \mathrm{~m}$ with diameter $0.60-1.60 \mathrm{~m}$. $94 \%$ of the wells have depth $2-10 \mathrm{~m}$ while the rest $6 \%$ wells have depth more than $10 \mathrm{~m}$. The highest depth $(15.1 \mathrm{~m})$ was measured in the well 31 which was present in a hilly plane (Bhomuraguri hill) and the corresponding lowest depth $(2.53 \mathrm{~m})$ was recorded in the well 38 , present in the alluvium plain. Surface material near the wells is generally composed of clay or sandy clay or silty clay. Geological horizon seems to have an older and younger alluvium. Aquifer material is also either sand, medium sand, coarse sand or clayey sand. The shallow sandy aquifer consists of clayey sand to sand with varying proportions of silt.

\section{Sample analysis}

The collected samples were analyzed for the parameters, viz., $\mathrm{As}, \mathrm{Fe}, \mathrm{Mn}, \mathrm{Ca}, \mathrm{Na}, \mathrm{K}, \mathrm{Mg}, \mathrm{pH}$ and $\mathrm{SO}_{4}{ }^{2-}$ following standard methods (APHA 1998). pH of the samples was measured at the site of collection using the $\mathrm{pH}$ meter (Merck, India), previously standardized by $\mathrm{pH} 4,7$, and 9 standard buffer solutions (procured from Merck, India). The instruments were calibrated and standardized before carrying out the analysis. $\mathrm{Na}$ and $\mathrm{K}$ in the water samples were determined by a flame photometer (Systronics, Germany), whereas $\mathrm{TH}, \mathrm{Ca}$, and $\mathrm{Mg}$ were determined by 
ethylenediaminetetraacetic acid titrametric methods. $\mathrm{SO}_{4}{ }^{2-}$ content present in the water samples were analyzed turbidimetrically at $450 \mathrm{~nm}$ using a UV-spectrophotometer. Hydride generation-atomic absorption spectrometry (HGAAS; Varian 220,USA) was used for analysis of As in water samples (detection limit $0.001 \mathrm{mg} / \mathrm{L}$ ). The results were further verified for accuracy by analyzing a few random samples in the ICP-MS. The data were subjected to Pearson correlation and cluster analysis using SPSS (Ver. 14.0). Cluster analysis was done by applying average linkage (between groups) and Pearson correlation method (hierarchical clustering), which was used as the measure of similarity. Before analyzing for clusters, the data were subjected to Pearson correlation between different water quality parameters of the study site.

\section{Results}

The basic statistics of As $(\mu \mathrm{g} / \mathrm{L})$ and Fe along with other parameters $(\mathrm{mg} / \mathrm{L})$ in the groundwater samples are given in Table 1. To confirm the normal distribution of each variable required for statistical analysis was checked by analyzing kurtosis and skewness statistical tests (Lattin et al. 2003). The original data showed that the skewness values ranged from -0.566 to 2.378 in the wet season and0.621-3.197 in the dry season while kurtosis values ranged from -0.918 to 7.393 in the wet season and -0.176 to 12.105 in the dry season, respectively, indicating normal distribution or close to normal distribution of the studied database. The anionic, As(III) and As(V), species were not speciated in this work and it is likely that the water contains only $\mathrm{As}(\mathrm{V})$ species (in the form of arsenate) due to atmospheric oxidation of As(III), if any. The mean arsenic concentration was in the range of BDL to $7.39 \mu \mathrm{g} / \mathrm{L}$ with a mean value of $1.92 \mu \mathrm{g} / \mathrm{L}$ (wet seasons) and from BDL to $13.80 \mu \mathrm{g} / \mathrm{L}$ with a mean value of $2.57 \mu \mathrm{g} / \mathrm{L}$ in the dry seasons (Khound et al. 2013). The highest arsenic concentration in the wet season $(7.39 \mu \mathrm{g} / \mathrm{L})$ and in the dry season $(13.80 \mu \mathrm{g} / \mathrm{L})$ was observed at the site 23 present in the foothills of Arunachal Himalaya for both the seasons. Except this source 23, all the aquifers of the study area show the arsenic content within the desirable limit of $10 \mu \mathrm{g} / \mathrm{L}$ (WHO 2004). The values are distributed in both the wet and dry seasons (Figs. 3,4) with different ranges as shown in the Table 2.

However, the studied river basin revealed that the As and Fe content aquifers were mostly found on the younger alluvium itself. It was also noticed that the depth-wise distribution and concentration level of As in the shallow aquifers followed an interesting pattern (Fig. 5). 6\% of the aquifers with depth 10-15 m, showed low arsenic concentration in the range of $\mathrm{BDL}-3.17 \mu \mathrm{g} / \mathrm{L}$ in both the seasons. Similarly, $92 \%$ of the samples, collected from aquifers of depths 2-9 $\mathrm{m}$ had an As concentration below the WHO limit of $10 \mu \mathrm{g} / \mathrm{L}$. The well 23 with the depth of $6.86 \mathrm{~m}$ present in the gravel area of the basin showed As concentration above the WHO permissible limit in all the seasons. The shallow aquifers of the study area show Mncontent in the range of $\mathrm{BDL}-0.83 \mathrm{mg} / \mathrm{L}$ in the wet seasons and BDL- $1.21 \mathrm{mg} / \mathrm{L}$ in the dry seasons. $34 \%$ of the samples in the wet seasons and $86 \%$ samples in the dry seasons from the shallow wells have $\mathrm{Mn}$ above the permissible limit of $0.1 \mathrm{mg} / \mathrm{L}$ (WHO, 1984). $80 \%$ of the groundwater samples of the study area have higher Mncontent in the dry seasons than in the wet seasons. However, the aquifers showed acid to alkaline $\mathrm{pH}$ from 5.6 to 7.6 in the wet seasons and from 5.9 to 7.4 in the dry seasons. Some of the sources had $\mathrm{pH}$ lower than the prescribed range of 6.5-8.5. Statistical analysis using Pearson correlation in Tables 3 and 4 shows that the parameters in the ground water samples were weakly and moderately correlated to each other at $p<0.01$ and $p<0.05$ levels. A good positive correlation was found to exist between As and Mn (0.041 and 0.044), $\mathrm{Na}$ (0.095 and 0.127), $\mathrm{Ca}(0.279$ and $0.217), \mathrm{Mg}(0.169$ and 0.249$), \mathrm{SO}_{4}{ }^{2-}(0.047$ and 0.283$)$ and

Table 1 Descriptive statistics of water quality parameters in the shallow aquifers

\begin{tabular}{|c|c|c|c|c|c|c|c|c|c|c|c|c|}
\hline & \multicolumn{2}{|c|}{ Minimum } & \multicolumn{2}{|c|}{ Maximum } & \multicolumn{2}{|l|}{ Mean } & \multicolumn{2}{|c|}{ Std. deviation } & \multicolumn{2}{|c|}{ Skewness } & \multicolumn{2}{|l|}{ Kutosis } \\
\hline & Wet & Dry & Wet & Dry & Wet & Dry & Wet & Dry & Wet & Dry & Wet & Dry \\
\hline As & BDL & BDL & 7.39 & 13.80 & 1.92 & 2.57 & 1.37 & 2.23 & 1.416 & 2.635 & 2.857 & 12.105 \\
\hline $\mathrm{Fe}$ & 0.12 & 0.16 & 4.45 & 7.80 & 0.97 & 1.02 & 0.97 & 1.54 & 1.982 & 3.197 & 3.474 & 10.712 \\
\hline $\mathrm{Mn}$ & BDL & 0.09 & 0.83 & 1.21 & 0.15 & 0.33 & 0.21 & 0.25 & 1.958 & 1.466 & 3.207 & 1.960 \\
\hline $\mathrm{pH}$ & 5.60 & 5.90 & 7.60 & 7.40 & 6.69 & 6.69 & 0.32 & 0.32 & -0.566 & -0.621 & 2.599 & 0.518 \\
\hline $\mathrm{Na}$ & 6.50 & 3.80 & 40.80 & 30.40 & 14.50 & 10.87 & 8.62 & 6.02 & 1.595 & 1.708 & 1.939 & 2.392 \\
\hline K & 2.60 & 2.00 & 22.70 & 16.70 & 8.41 & 5.41 & 4.26 & 3.19 & 1.538 & 1.688 & 2.918 & 2.880 \\
\hline $\mathrm{Ca}$ & 9.30 & 7.10 & 43.90 & 39.90 & 23.89 & 18.02 & 10.01 & 7.97 & 0.437 & 0.953 & -0.918 & 0.312 \\
\hline $\mathrm{Mg}$ & 2.10 & 2.60 & 25.90 & 17.30 & 9.48 & 7.93 & 4.98 & 3.51 & 1.026 & 0.863 & 1.122 & 0.396 \\
\hline $\mathrm{SO}_{4}$ & 7.10 & 3.10 & 83.10 & 38.00 & 21.42 & 18.15 & 14.07 & 7.68 & 2.378 & 0.338 & 7.393 & -0.176 \\
\hline
\end{tabular}




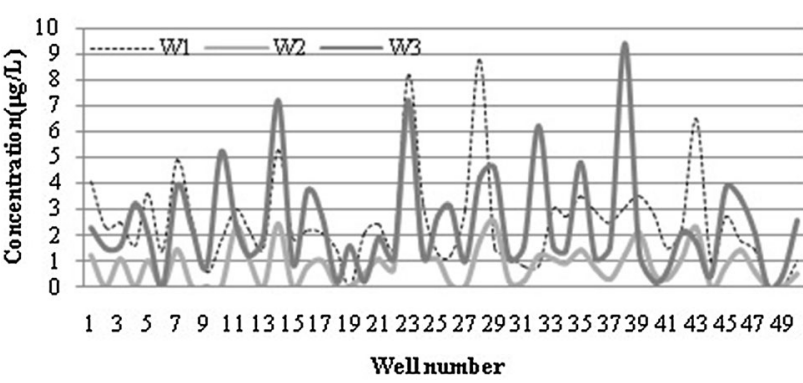

Fig. 3 Arsenic-content $(\mu \mathrm{g} / \mathrm{L})$ of the shallow wells in the wet seasons $(W 1, W 2$ and $W 3)$

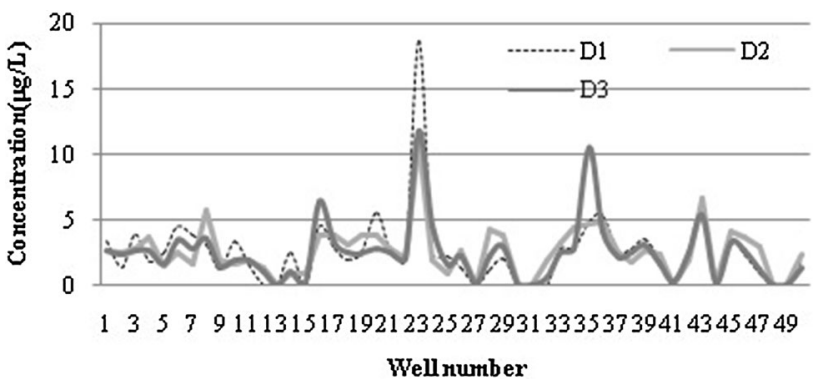

Fig. 4 Arsenic Content ( $\mu \mathrm{g} / \mathrm{L})$ of the shallow wells in the dry seasons $(D 1, D 2$ and $D 3)$

Table 2 Distribution of shallow wells in different range of As content

\begin{tabular}{llc}
\hline Arsenic range & \multicolumn{2}{l}{ No. of shallow wells } \\
\cline { 2 - 3 } & Wet season & Dry season \\
\hline BDL & 1 & 4 \\
$<1.0 \mu \mathrm{g} / \mathrm{L}$ & 10 & 6 \\
$1.0-10.0 \mu \mathrm{g} / \mathrm{L}$ & 39 & 39 \\
$>10 \mu \mathrm{g} / \mathrm{L}$ & $\mathrm{NIL}$ & 1 \\
Total & 50 & 50 \\
\hline
\end{tabular}

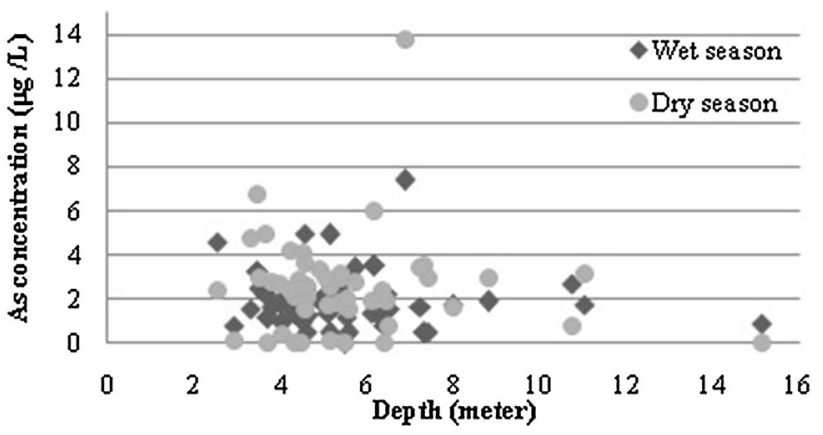

Fig. 5 Depth wise distribution of Arsenic in the shallow aquifers

$\mathrm{pH}(0.188$ and 0.118$)$ in both the wet and dry season, respectively. Correlations between $\mathrm{Fe}$ and $\mathrm{Mn}(0.147$ and $0.197), \mathrm{Na}(0.027$ and 0.057$), \mathrm{Ca}(0.0 .081$ and 0.169$), \mathrm{Mg}$ (0.0.071 and 0.042) and $\mathrm{SO}_{4}{ }^{2-}(0.070$ and 0.122$)$ at $p<0.01$ were also observed for both wet and dry season, respectively, in the collected groundwater samples of the study area.

Similar correlations were also observed between $\mathrm{Mn}$ and $\mathrm{Na}(0.319), \mathrm{K}(0.245), \mathrm{Ca}(0.142), \mathrm{Mg}(0.125), \mathrm{SO}_{4}{ }^{2-}$ $(0.078)$ in the wet season while strong correlation between $\mathrm{pH}$ and $\mathrm{Ca}$ (0.381 and 0.384), $\mathrm{Mg}\left(0.206\right.$ and 0.523) $\mathrm{SO}_{4}{ }^{2-}$ (0.163 and 0.271), $\mathrm{Na}$ and $\mathrm{Ca}(0.344$ and 0.371$), \mathrm{Mg}(0.514$ and 0.427), $\mathrm{SO}_{4}{ }^{2-}\left(0.493\right.$ and 0.552), and $\mathrm{SO}_{4}{ }^{2-}$ and $\mathrm{Ca}$ (0.606 and 0.621), $\mathrm{Mg}(0.787$ and 0.631$)$ was observed in both the seasons. Again, a strong positive correlation was found between (i) $\mathrm{Ca}$ and $\mathrm{Mg}(0.778$ and 0.882$)$ and $\mathrm{Na}$ and $\mathrm{K}(0.464$ and 0.856$)$ for both seasons. In this study, cluster analysis was employed to detect similarity and dissimilarity groups between the water quality variables of the collected groundwater samples. The dendrogram in Figs. 6 and 7 showed two main distinct clusters for water quality parameters of the study area in both the seasons. Cluster 1 includes the water quality parameters $\mathrm{As}, \mathrm{Ca}, \mathrm{Mg}, \mathrm{Na}, \mathrm{K}$, $\mathrm{Mn}$ and $\mathrm{SO}_{4}{ }^{2-}$ while Cluster 2 included only one parameter, $\mathrm{Fe}$ in the wet season. However, in the dry season $\mathrm{Mn}$ shifted to the cluster 2 while Cluster 1 remains with other parameters.

\section{Discussion}

The present study indicated the distribution of Arsenic as well as other heavy metals like $\mathrm{Ca}, \mathrm{Mg}, \mathrm{Na}, \mathrm{K}$ and $\mathrm{Fe}$ in the shallow aquifers of Jia Bharali river basin of Assam, India. It was revealed that the residents of the area had been chronically exposed to high levels (above the permissible limit of the WHO/BIS) of As and $\mathrm{Fe}$ in comparison with the highly As-exposed populations of the adjoining regions like West Bengal, India (Mukherjee et al. 2006; Nickson et al. 2007) and Bangladesh (Bhattacharya et al. 2007; Halem et al. 2009). This area is mainly within the quaternary alluvial basin (Ground Water Information Booklet 2008) bounded by the Himalayan Mountains. However, most of the well present in the alluvium both younger and older, within the safe limit (WHO 1984, $10 \mu \mathrm{g} / \mathrm{L}$ ) for drinking purposes. The probable reason for As content might be heavy deposition of sediments through leaching from surrounding mountains (Singh 2004). Mobilization of As in ground waters of Gangetic delta of West Bengal, India and Bangladesh had already been proposed by several workers (Rmalli et al. 2005; McArthur et al. 2004; Bhattacharya et al. 2006). Sedimentology, the northeastern part of India, especially Assam region, is related to that of the Bangladesh plains (Enmark and Nordborg 2007). Therefore, the adjoining North Brahmaputra Plain, the site of our interest, might be expected to follow the comparable way in respect to the mobilization of As in groundwater. In addition, the present 
Table 3 Correlation matrix of the trace metal variables in the wet season

\begin{tabular}{|c|c|c|c|c|c|c|c|c|c|}
\hline & As & $\mathrm{Fe}$ & Mn & $\mathrm{PH}$ & $\mathrm{Na}$ & $\mathrm{K}$ & $\mathrm{Ca}$ & $\mathrm{Mg}$ & $\mathrm{SO}_{4}$ \\
\hline As & 1.000 & -0.116 & 0.041 & 0.188 & 0.095 & -0.004 & 0.279 & 0.169 & 0.047 \\
\hline $\mathrm{Fe}$ & -0.116 & 1.000 & 0.147 & 0.012 & 0.027 & -0.276 & 0.081 & 0.077 & 0.070 \\
\hline $\mathrm{Mn}$ & 0.041 & 0.147 & 1.000 & -0.189 & 0.319 & 0.245 & 0.142 & 0.125 & 0.078 \\
\hline $\mathrm{pH}$ & 0.188 & 0.012 & -0.189 & 1.000 & -0.111 & 0.059 & 0.381 & 0.206 & 0.163 \\
\hline $\mathrm{Na}$ & 0.095 & 0.027 & 0.319 & -0.111 & 1.000 & 0.464 & 0.344 & 0.514 & 0.493 \\
\hline K & -0.004 & -0.276 & 0.245 & 0.059 & 0.464 & 1.000 & 0.263 & 0.427 & 0.495 \\
\hline $\mathrm{Ca}$ & 0.279 & 0.081 & 0.142 & 0.381 & 0.344 & 0.263 & 1.000 & 0.778 & 0.606 \\
\hline $\mathrm{Mg}$ & 0.169 & 0.077 & 0.125 & 0.206 & 0.514 & 0.427 & 0.778 & 1.000 & 0.787 \\
\hline $\mathrm{SO}_{4}$ & 0.047 & 0.070 & 0.078 & 0.163 & 0.493 & 0.495 & 0.606 & 0.787 & 1.000 \\
\hline
\end{tabular}

Bold values are used to make a clear visibilty between the correlated variables

Table 4 Correlation matrix of the trace metal variables in the dry season

\begin{tabular}{|c|c|c|c|c|c|c|c|c|c|}
\hline & As & $\mathrm{Fe}$ & Mn & PH & $\mathrm{Na}$ & K & $\mathrm{Ca}$ & $\mathrm{Mg}$ & $\mathrm{SO}_{4}$ \\
\hline As & 1.000 & -0.082 & 0.044 & 0.118 & 0.127 & 0.221 & 0.217 & 0.249 & 0.283 \\
\hline $\mathrm{Fe}$ & -0.082 & 1.000 & 0.197 & -0.073 & 0.057 & -0.088 & 0.169 & 0.042 & 0.122 \\
\hline $\mathrm{Mn}$ & 0.044 & 0.197 & 1.000 & -0.035 & -0.090 & 0.031 & 0.104 & -0.007 & -0.040 \\
\hline $\mathrm{pH}$ & 0.118 & -0.073 & -0.035 & 1.000 & 0.283 & 0.288 & 0.384 & 0.523 & 0.271 \\
\hline $\mathrm{Na}$ & 0.127 & 0.057 & -0.090 & 0.283 & 1.000 & 0.856 & 0.371 & 0.427 & 0.552 \\
\hline K & 0.221 & -0.088 & 0.031 & 0.288 & 0.856 & 1.000 & 0.390 & 0.410 & 0.560 \\
\hline $\mathrm{Ca}$ & 0.217 & 0.169 & 0.104 & 0.384 & 0.371 & 0.390 & 1.000 & 0.822 & 0.621 \\
\hline $\mathrm{Mg}$ & 0.249 & 0.042 & -0.007 & 0.523 & 0.427 & 0.410 & 0.822 & 1.000 & 0.631 \\
\hline $\mathrm{SO}_{4}$ & 0.283 & 0.122 & -0.040 & 0.271 & 0.552 & 0.560 & 0.621 & 0.631 & 1.000 \\
\hline
\end{tabular}

Bold values are used to make a clear visibilty between the correlated variables

Dendrograro using Average Linkage (Betveen Groups)

Rescaled Distance Cluster Combine

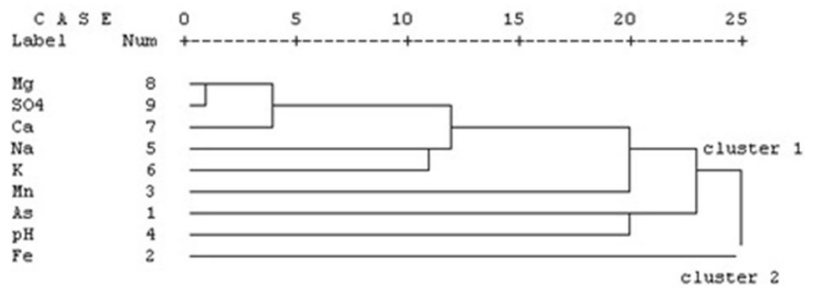

Fig. 6 Dendrogram showing the clusters of different water quality parameters in the wet season

study revealed that the quaternary alluvium deposits, especially the younger regions were more As-contaminated, in comparison to the older one. Researchers Smedley and Kinniburgh (2002), McArthur et al. (2004), and Bhattacharya et al. (2006) proposed the importance of reductive dissolution of metal (iron) oxide/hydroxide and subsequent release of the adsorbed As, in the process of its mobilization. The degradation of organic matter present in the aquifers might also be involved in the reductive dissolution of the iron hydroxide, causing desorption of any adsorbed As (Parkhurst
Dendrogram using average Linkage (Betveen Groups)

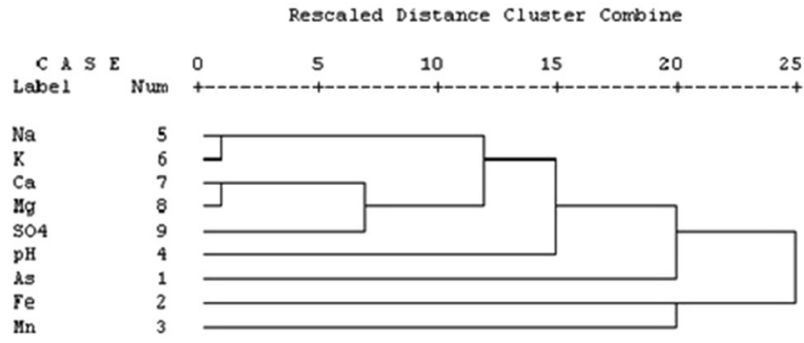

Fig. 7 Dendrogram showing the clusters of different water quality parameters in the dry season

1995). Moreover, Fe hydroxides, carrying a surface charge, could adsorb the electrically charged As ions which is a pHdependent process and related to the net charge of the adsorbing surface (Parkhurst 1995). Generation of As oxyanionic species through oxidative dissolution of the Asbearing pyrite minerals could be another basis of contamination of the groundwater tables (Acharyya et al. 1999; Nickson et al. 2000). Arsenic-bearing pyrite works as an authigenic phase in alluvial aquifers (Saunders et al., 1997; Nickson et al., 2000), which has led some to propose that Fe 
sulfide solids are important sources or sinks of As in groundwater. However, the presence of $\mathrm{SO}_{4}{ }^{2-}$ in the aquifers of the studied river basin having a positive correlation with As in both the seasons ( 0.047 in the wet season and 0.283 in the dry seasons) could also be one of the possible sources of As mobilization through which As enters the water environment by the oxidation of the sulfide ores of As (Acharyya et al. 1999). Again, extensive household activities such as bathing and washing facilitated microorganisms to release arsenic-involving bio electrochemical reactions in the studied aquifers (Dey et al. 2005). Again, a positive correlation between As and Mn (0.041in the wet season and 0.044 in the dry season) indicated that the aquifers of the study area might have some common natural sources of pollution through which mobilization of $\mathrm{As}, \mathrm{Fe}$, and Mn was taking place. The high incidence of As content was noted greater in the western parts of the basin compared to the eastern part. Potential aquifers pertained to the quaternary formation have unique subsurface geology. Over withdrawal of groundwater in the study region for agriculture practices and household uses might be another strong reason for the arsenic mobilization (Bhattacharjee et al. 2005).

\section{Conclusion}

This paper represented the groundwater quality in the Jia Bharali river basin with respect to arsenic and other parameters. The mitigation strategy for the problem in the area might be specific to the location, taking into considerations the geomorphological variations and socioeconomic conditions. Understanding the groundwater movements requires in-depth characterization and routine verification of physical hydrogeology. Cost-effective and user-friendly technologies providing pure water are required to counter the serious health hazards by giving Asand/or Fe-contaminated water.

Acknowledgements The present study was carried out under the Department of Science and Technology, Govt. of India sponsored project SR/S4/ES-21/BRAHMAPUTRAII/2005/(P-1).

Open Access This article is distributed under the terms of the Creative Commons Attribution 4.0 International License (http:// creativecommons.org/licenses/by/4.0/), which permits unrestricted use, distribution, and reproduction in any medium, provided you give appropriate credit to the original author(s) and the source, provide a link to the Creative Commons license, and indicate if changes were made.

\section{References}

Acharyya SK ( 2001) in Sem. Water Resour. Manage. in Lower Ganga Plains, Geol. Min. Met. Soc. India, Abstr., Kolkata, March, p 3
Acharyya SK, Chakraborty P, Lahiri S, Raymahashay BC, Guha S, Bhowmik A (1999) Arsenic poisoning in the Ganges Delta. Nature 401:545

Ali I (2012) New generation adsorbents for water treatment. Chem Revs (ACS) 112:5073-5091

Ali I, Aboul-Enein HY (2002) Speciation of arsenic and chromium metal ions by reversed phase high performance liquid chromatography. Chemosphere 48(3):275-278

Ali I, Jain CK (2004) Advances in arsenic speciation techniques. Int J Environ Anal Chem 84(12):947-964

Ali I, Hassan Y, Enein A (2006) Instrumental methods in metal ion speciation, CRC Press

Ali I, Tabrez A, Asim M (2011) Removal of arsenic from water by electrocoagulation and electrodialysis techniques. Sep Purif Rev 40(1):25-42

Aloupi M, Angelidis MO, Gavriil AM, Koulousaris M, Varnavas M (2009) Influence of geology on arsenic concentrations in ground and surface water in central Lesvos, Greece. Environ Monit Assess 151(1-4):383-396

APHA, AWWA (American Public Health Association) (1998) Standard methods for the examination of water and wastewater, American Public Health Association, Washington, DC

Bhattacharjee S, Chakravarty S, Maity S, Dureja V, Gupta KK (2005) Metal content in groundwater of Sahebgunj district, Jharkhand, India, with special reference to arsenic. Chemospere 58:1203-1217

Bhattacharya P, Ahmed KM, Broms S, Fogelström J, Jacks G, Sracek $\mathrm{O}$ et al (2006) Mobility of arsenic in groundwater in a part of Brahmanbaria district, NE Bangladesh. In: Naidu R, Smith E, Owens G, Bhattacharya P, Nadebaum P (eds) Managing arsenic in the environment: From soil to human health. CSIRO Publishing, Melbourne, pp 95-115

Bhattacharya P, Welch AH, Stollenwerk KG, McLaughlin MJ, Bundschuh J, Panaullah G (2007) Arsenic in the environment: biology and chemistry. Sci Total Environ 379:109-120

Bissen M, Frimmel FH (2003) Arsenic - a review. Part I: occurrence, toxicity, speciation, mobility. Acta Hydrochim Hydrobiol 31(1):9-18

Chetia M, Singh SK, Bora K, Kalita H, Saikia LB, Goawami DC et al (2008) Groundwater arsenic contamination in three blocks of Golaghat district of Assam. J Indian Water Works Assoc 40(2):150-154

Chetia M, Chatterjee S, Banerjee S, Nath MJ, Singh L, Srivastava RB, Sarma HP (2011) Groundwater arsenic contamination in the Brahmaputra River basin: a water quality assessment in the Golaghat (Assam), India. Environ Monit Assess 173:371-385

Das B, Rahman MM, Nayak B, Pal A, Chowdhury UK, Mukherjee SC et al (2009) Groundwater arsenic contamination, its health effects and approach for mitigation in West Bengal, India and Bangladesh. Water Quality Exposure Health 1:5-21

Dey S, Chatterjee S, Sarkar S (2005) Direct and indirect arsenic release from soaps by unhygienic use in Tubewells. Curr Sci 89(11):1913-1917

Elster EF, Wagner GA, Schutz W (1988) Activated oxygen in green plants in relation to stress situation. Curr Topics Plant Biochem Physiol 7:159-187

Enmark G, Nordborg D (2007) Arsenic in the groundwaterof the Brahmaputra floodplains, Assam, India—source, distribution and release mechanisms. Minor Field Study 131, Committee of Tropical Ecology, Uppsala University, Uppsala, Sweden, p 35, ISSN: 1653-5634

Ground Water Information Booklet (2008). Golaghat District, Assam, Ministry of Water Resources, Guwahati

Halem DV, Bakker SA, Amy GL, Van Dijk JC (2009) Arsenic in drinking water: not just a problem for Bangladesh. Drink Water Eng Sci Discuss 2:51-64

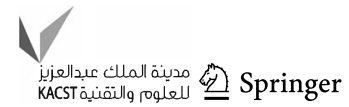


Imran Ali, Gupta Vinod K, Khan Tabrez A, Asim Mohd (2012) Department Removal of arsenate from aqueous solution by electro-coagulation method using Al-Fe electrodes. Int J Electrochem Sci 7:1898-1907

Jain SK, Agarwal PK, Singh VP (2007) Hydrology and water resources of India. Springer, Dordrecht. (13-978-1-4020-5180-7, e-book)

Khound NJ, Phukon P, Bhattacharyya KG (2013) Assessment of dissolved trace metals in the shallow aquifers of the Jia Bharali River Basin, Assam, India, Journal of Geological Society of India, Springer, vol. 82, pp 162-168. ISSN: 0974-6889

Lattin J, Carroll D, Green P (2003) Analyzing multivariate data. Duxbury, New York

Mahanta C, Enmark G, Nordborg D, Sracek O, Nath B, Nickson RT, Herber R, Jacks G, Mukherjee A, Ramanathai AL, Choudhury R, Bhattacharya P (2015) Hydrogeochemical controls on mobilization of arsenic in groundwater of a part of Brahmaputra River floodplain, India. J Hydrol Reg Stud 4(part A):154-171

Mandal BK, Suzuki KT (2002) Arsenic round the world: a review. Talanta 58:201-235

Matin AK, Bhattacharya P, Aziz Hasan M, Humayun Akhter S, MahbubAlam SM, Hossain Bhuyian MA et al (2004) Arsenic enrichment in groundwater of the alluvial aquifers in Bangladesh: an overview. Appl Geochem 19(2):181-200

McArthur JM, Banerjee DM, Hudson-Edwards KA, Mishra R, Purohit R, Ravenscroft P et al (2004) Natural organic matter in sedimentary basins and its relation to arsenic in anoxic groundwater: the example of West Bengal and its worldwide implications. Appl Geochem 19:1255-1293

Mukherjee A, Sengupta MK, Hossain MA, Ahmed S, Das B, Nayak B et al (2006) Arsenic contamination in groundwater: A global perspective with emphasis on the Asian scenario. Journal of Health Population and Nutrition 24(2):142-163
Nickson RT, McArthur JM, Ravenscroft P, Burgess WG, Ahmed KM (2000) Mechanism of arsenic release to groundwater, Bangladesh and WestBengal. J Appl Geochem 15(4):403-413

Nickson R, Sengupta C, Mitra P, Dave SN, Banerjee AK, Bhattacharya A et al (2007) Current knowledge on the distribution of arsenic in groundwater in five states of India. Journal of Environmental Science and Health Part A 42:1707-1718

Parkhurst DL (1995) User's guide to PHREEQC - a computer program for speciation, reaction path, advective transport and inverse geochemical calculations (pp 143). Washington: US Geological Service, Water Resources Investigations, 95-4227

Rmalli SWA, Harrington CF, Ayub M, Haris PI (2005) A biomaterial based approach for arsenic release to groundwater, Bangladesh \& West Bengal. Journal of Environmental Monitoring 7:279-282

Saunders JA, Pritchett MA, Cook RB (1997) Geochemistry of biogenic pyrite and ferromanganese stream coatings: a bacterial connection? Geomicrobiol. J. 14:203-217

Sharma VK, Sohn M (2009) Aquatic arsenic: toxicity, speciation, transformations, and remediation. Environ Int 35:743-759

Singh AK (2004) Arsenic contamination in groundwater of Northeastern India. In: Proceedings of 11th national symposium on hydrology with focal theme on water quality, National Institute of Hydrology, Roorkee, pp 255-262

Smedley PL, Kinniburgh DG (2002) A review of the source, behaviour and distribution of arsenic in natural waters. Appl Geochem 17:517-568

Smith AH, Lopipero PA, Bates MN, Steinmaus CM (2002) Arsenic epidemiology and drinking water standards. Science 269:2145-2146

WHO (2004) Guidelines for drinking-water quality (Vol. 1, 3rd edn. World Health Organization, Geneva 